\title{
Identification of a crime perpretator based on trace evidence
}

\author{
Dariusz Szydłowski ${ }^{1}$ \\ ${ }^{1}$ Department of Law and Social Science, Bielsko-Biala School of Finance and Law \\ ul. Tańskiego 5, 43-382 Bielsko-Biała
}

\begin{abstract}
The application of advanced methods of trace identification at a crime scene has made a substantial contribution to the identification of offenders. An accurate identification as well as preservation of forensic traces at a crime scene are key determinants of the methods' usage. The application of appropriate forensic traces identification and preservation techniques has been presented in the paper, including selected case studies.
\end{abstract}

Index Terms - forensic identification, forensic traces, trace evidence.

\section{INTRODUCTION}

Nowadays trace evidence analysis constitutes an integral component of forensic techniques. Since the beginning of mankind use of traces has been a significant element designed to identify and impact on a safety of a given environment. In the 20th century along with dynamic scientific and technological development, traces analyses have deeply influenced the effectiveness of identification of offenders and allowed to conduct comparative tests. Trace evidence may be found at every place of incident. From a rational point of view, a perpetrator must get to the crime scene, stay there and return. Offenders always leaves traces of their actions.

A consistent search and an adequate preservation of forensic evidence are the most important aspects in forensics. Any mistake or negligence on the part of a forensic technician threatens the continuation of a method of proceeding. Both in urban and rural areas, crime may be counted among the most important social problems. A proper forensic work of technicians depends on the appropriate use of their findings. However, the results of that hard and responsible work are used only to a small extent, although they are of great importance in solving a criminal case. At present, the collected traces of footwear soles secured at places of incidents are stored at the Voivodeship Trace Evidence Register which greatly facilitates preparatory proceedings.

\section{II.FORENSIC IDENTIFICATION}

Since the beginning of mankind identification of persons and objects has proved particularly difficult, but now it is the main focus of forensics (Kulicki, Stępka and KwiatkowskaWójcikiewicz, 2009). Forensic identification primarily refers to a variety of findings related to the course of events, ending with the investigation of acquired traces (Moszczyński, 2016). It includes scientific methods of conduct in determining the perpetrator who left a mark. Forensic identification is an important element resulting from a criminal proceeding, and it is a part of each stage of proceedings, from recognition, detection, proof to prevention (Kędzierska, 2007). The use of the adjective forensic together with the word identification reveals its distinctiveness in relation to other methods of identification. This is due to 'a small amount of evidence, its unlimited generality, uniqueness of identification situations' (Kędzierska, 2007). Identification embraces two very important meanings: the first is a research process, often developmental therefore considered dynamic. The process is also regarded as recognition, comparing, and identification. The second stage is the result of the research process, which is assumed to be static because it is a result, and above all, the end of the research process. The identification is a result of the research process.

The definition of identification may be divided into narrow and broad. The narrow definition of identification determines only the origin of the trace, whereas the broad definition covers everything that is outside the research process, inter alia: a type of incident, circumstances of the incident, detection of a perpetrator (Kędzierska, 2007). It may be claimed that forensic identification is 'the determination of the identity of a person, an animal or an object by comparing them with someone or something, or by recognition' (Kędzierska, 2007).

The basis of identification are material identification features. Each feature that an object possesses enables a certain

\author{
ASEJ - Scientific Journal of Bielsko-Biala School of \\ Finance and Law \\ Volume 22, No 3 (2018), pages 8 \\ DOI: $10.5604 / 01.3001 .0012 .7903$
}

Received 04 September 2018; Accepted 23 October 2018

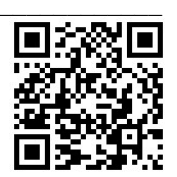

Regular research paper: Published 30 October 2018

Corresponding author's e-mail: szydlowski@autograf.pl

Copyright (C) 2018 This is an open access article distributed under the

Creative Commons Attribution CC-BY-NC 4.0 License. 
type of identification, and it is also a forensic feature. In a research where the amount of evidence proves to be insufficient, only available features are taken into account. The term identification demonstrates only the usefulness of a feature, not its essence. Identification feature concerns both living beings and activities carried out by them, as well as things. When it comes to humans one may distinguish, inter alia: smell, fingerprints, hair colour, and the colour of hair in case of animals. Objects may be identified inter alia: by texture, loss, scratches, joining elements and size. Identification features are always connected with an object. Various situations may occur during an incident, for example a whole vehicle is considered to be a trace, therefore all its features may be used for the identification process. In a case when a part of an object is approved to be a mark, features of a given element are used for research. However if an object's features are transferred to a carrier, then the transfer becomes a trace with a limited number of features.

Important elements of identification process include: the number of features - the more features, the greater probability of determining the positive or negative result, quality, distinctness, durability, reliability of connection with an element, interchangeability of features, distinctive features, features indicating the specificity of an object. Identification features in forensics may be classified as follows:

TABLE 1. CLASSIFICATION OF IDENTIFICATION FEATURES IN FORENSICS

\begin{tabular}{|r|l|l|}
\hline & Classification & Explanation (what it concerns) \\
\hline \multirow{2}{*}{1.} & Unit & $\begin{array}{c}\text { Re shape of e.g. ear, lips, a colour of e.g. } \\
\text { skin }\end{array}$ \\
\cline { 2 - 3 } & Group & Re e.g. type of weapon, typewriter type \\
\hline \multirow{2}{*}{2.} & Qualitative & Re type of trace \\
\cline { 2 - 3 } & Quantitative & Re trace dimension \\
\hline \multirow{2}{*}{3.} & Simple & Re trace length of footwear sole \\
\cline { 2 - 3 } & Complex & Re shape size of footwear features \\
\hline \multirow{2}{*}{4.} & Internal & Re density \\
\cline { 2 - 3 } & External & Re external features e.g. cavities \\
\hline \multirow{2}{*}{5.} & General & Re a whole object creating a trace \\
\cline { 2 - 3 } & Detailed & Re specific area of an object \\
\hline \multirow{2}{*}{6.} & Group & Feature characterising a group \\
\cline { 2 - 3 } & Individual & Applies to a unit \\
\hline \multirow{2}{*}{7.} & Specific & Specific for a given object \\
\cline { 2 - 3 } & Diagnostic & $\begin{array}{c}\text { Characteristic for a given type, make } \\
\text { recognition easier }\end{array}$ \\
\hline
\end{tabular}

Source: Own description based on (Kędzierska, 2007)

The division into individual identification and group identification is the most popular typology, in such case names of types have been borrowed from features names 'according to the number of identified objects' (Kędzierska, 2007). The features of human beings are both individual and collective, they are primarily genetically conditioned. Moreover, a person's characteristic traits are acquired throughout life. This happens due to biological processes such as: aging, diseases and their treatment, also through work and favourite entertainment. Objects first acquire characteristics during production stage, then during use, renovation, and modification. All aspects are interrelated because what is destroyed requires repair which alters the current features. Forensics strives for individual identification. However, it all depends on many factors such as: the level of knowledge, the degree of development of a given field, the quality and quantity of the material that is tested, and circumstances. The most important determinant in forensics is the trace and its types. Therefore, it is possible to single out individual information about the origin of the object. This information must have scientific justification.

Forensic identification is a process which must meet the conditions resulting from three important elements such as: the subject, the method and the number of identification stages (Kędzierska, 2007). The first mentioned criterion refers to the subject, it includes a procedural body, a victim, a witness, an expert as well as the perpetrator. They all are a part of forensic identification. The method as a basis for identification may distinguish several types, inter alia: chemical, biological, economic or forensic. The method criterion is not complex as methods employed during identification. Forensics as a science has its own, original research methods.

Next criterion is the number of stages, therefore one may distinguish indirect and direct traces. During each conducted identification a trace becomes the starting point. However, the law enforcement authority does not deal with the trace itself but with the information who the trail belongs to. Identification is supposed to determine the identity of the person who has left the mark. Regarding the number of stages one may distinguish two types of identification: indirect and direct. Direct, one- step identification allows for the recognition of the owner based on the mark itself e.g. fingerprint, dentition traces, also handwriting. Indirect identification called a multi-stage, consists of at least two phases. It gradually endeavours to identify the perpetrator's identity. The examples of indirect traces are inter alia: traces of a tool revealed during the inspection of a place the crime scene, groups of people with an access to the tool. The number of stages and their type depends on the way of disclosure and the trace preservation. Trace identification and apprehending the perpetrator are the last stages in the identification process. The result of the research process may be obtained through the following elements: the object of identification, the number of identified objects and conclusions.

As far as the object of identification is concerned, a person, body, animals, a thing, a place as well as activities are taken into account. Disclosure and preservation of the trace will lead to one of the above elements. The example of such disclosure is a track of speech registered on a tape or other carrier enabling a person's identification. The number of identified objects leaving a trail is the next element (Kędzierska, 2007). T. Hanausek differentiated between two types of identification: a group identification which occurs when the object of identification mentioned earlier possesses identical features as objects classified to that group before, and individual identification that demonstrates the fact that an object presenting the same features decides about how it will be named and why it will be marked in such a way. The above division detects two terms: identical and same. The identical features refer only to one object, whereas same ones are similar in several objects (Hanausek, 1994). Often a group identification 
becomes a stage leading to an individual identification. Both identification types mentioned by Hanausek are mainly the result of interpersonal relations of traces investigation.

The number of features in a trace is a more important criterion as far as individual and group identification division is concerned. It refers to a process of individualisation where application of new research methods allows for a gradual shift of a group identification towards the individual one. The process constitutes an essential component of investigation work during an operation of suspects elimination. Objects of interest include traces such as hair, saliva, blood, semen, and also some traces in the field of physiochemical tests e.g. fibre. Individual identification only enables determination if a given person came into contact with a specific object, or was present at the place of the incident, however it does not confirm the fact that the person was really the perpetrator (Kędzierska, 2007).

The last criterion refers to conclusions indicating positive and negative identification (Kędzierska, 2007). Identification as a research process is referred to as identification survey. One may distinguish two types of identification surveys: identification tests and comparative study. In both identification surveys, assignment of features present in the tested material is crucial. The material is selected in pairs. The difference between surveys depends only on the type of the problem under investigation (Kędzierska, 2007).

The purpose of identification surveys is 'to determine the identity of the object creating the trace by recognizing it' (Kedzierska, 2007). Identification test must answer the question regarding the identity of the object that had left the mark. The examples of objects are inter alia: fragments of plants, strange material stains, unknown liquids. During a given object investigation further detailed questions appear (Kędzierska, 2007).

The following types of material may be differentiated: the evidence - include all traces preserved at the scene of an incident regardless of whether they will be qualified to individual or group identification (Kulicki, 1994). The evidence not only includes forensic traces but also everything that could be related to the event, while material not classified as trace, is eliminated in further stages of testing (Kędzierska, 2007), comparative material - encloses intentionally obtained traces, in order to identify the perpetrator, for example material collected in appropriate databases (fingerprints), and also in forensic collections (footwear bottoms, broken locks equipment, weapon) (Kulicki, 1994). Comparative material is the result of evidence material. One may distinguish between two forms of material: an object, or a comparative trace. Comparative material is obtained for testing in a form of biological swab e.g. of shoes. As far as control material is concerned, it refers to the whole object or to its part, and also a sample from the collected substrate, on which the trace was made. During trace preservation at the scene of the incident, frequently a part of substrate is taken as a carrier. Receiving such material is intended to eliminate the evidence from the ground and determining its effect on change as well as destruction of the trace identification features. Standard reference material relates to the object with permanent, objective and scientifically determined features, which constitute a comparative unit during identification tests. Standard reference material is easily accessible as it is not required to possess special permissions to receive it (Kędzierska, 2007).

Comparative studies intend to 'determine an object's identity from which the trail comes by comparison' (Kędzierska, 2007). Each testing both comparative and identifying is completed by obtaining the result which is also an opinion on a given issue. The opinion may be categorical, that is positive and negative, as well as alternative, that is a probability (Kędzierska, 2007).

\section{III.FORENSIC TRACE}

The definition of a forensic trace has been evolving over years along with the development of forensics. The first definition referred to objects which could have been regarded as a forensic trace. In the following stage of the trace definition development there was a word change i.e. the removal of trace calculations and its substitution with the term of changes. The third stage included adding information about incidents written in human consciousness. One may conclude that the change in knowledge possessed by a human was also perceived as a forensic trace.

The term forensic trace is constantly changing, along with human consciousness (Kędzierska, 2011). The most popular definition belongs to Jan Sehn: 'a trace in the forensic sense includes any changes in objective reality, which as observable marks after the events being the subject of proceedings, constitute the basis for reproducing the course of these events in accordance with reality' (Kędzierska, 2011). However, a different definition may also be employed. This definition was proposed by authors of a popular forensic textbook written under the editorship of J. Widacki. The authors claim that' traces are certain, special, noticeable remnants of events' (Widacki, 1984). Another definition of forensic trace is provided by T. Hanausek, according to whom forensic trace is 'all identifiable in a specific part of reality consequences of these changes, which group either create an event, or is closely linked with this event (e.g. traces of escape, traces of concealing the booty etc.)' (Hanausek, 1975). B. Hołyst claims that, 'each change of appearance (e.g. shape, colour), or place of an object and deformation of the substrate as well as residual substance, objects etc. which raise suspicion to be related to an investigated event, may be named as a trace in forensics' (Hołyst, 2010).

Many divisions of traces may be distinguished in the literature. G. Kędzierska demonstrates the most extensive classification of traces. The basic division is separation of substance and memory traces - the terms have been accepted conventionally. The mentioned classification may be regarded as the example of a general trace division. Based on stages of criminal activity, traces also may be separated into: traces arising with the intent to commit a prohibited act, traces created during preparation, traces created during the crime, and the ones created just after the crime in the process of obliterating the marks. 
Another division is based on a trace carrier and it refers to traces found on objects, human bodies (of a victim, a witness, a perpetrator), and on the body of animals. Due to the size of material traces, they may be divided into macro and micro traces. In the literature there is also a distinction according to an individual that had left the trace, whether he was a perpetrator, a victim, a witness, or other person. It is quite clear that based on a trace one may obtain information about a prohibited act itself as well as persons involved in such an event. Due to the process, a trace is created, a projection, stains, and other trails may be distinguished.

While attempting to precisely classify traces, it may be noticed that there are many divisions, and some of traces cannot be disconnected. Often, one trace contains double information (Kędzierska, 2011).

According to S. Kozdrowski traces may be distributed because of their outer form into surface prints - formed on a hard surface, and those in turn on layered prints - created by applying a trace on a substrate with the help of substance on the object e.g. mud, flour, oil (Kozdrowski, 2012) and exfoliated prints - formed when a surface is covered with a substance, part of which is found on the object, e.g. crossing in footwear through freshly painted pedestrian crossing, leaving a mark in a form of surface prints with paint used for painting a pedestrian crossing, and finally corrugated prints - created on a soft surface e.g. an imprint of bare foot in mud.

Next division includes layered and exfoliated prints. Additionally, stains may be differentiated - remains of substances of irregular shape, differing in colour of the ground, often stains have their own specific smell. Objects and their parts - all will be found at the place of incident, for example a knife, a crowbar, and also fragments of a padlock. Smells - a trace is an effect of evaporation of a given substance. Changes in the geometry of objects - include all of objects' distortion, e.g. bent trellis in a window. Negative positioning - refers to all differences in objects' location before the event, possibly a lack of the objects. Thermal traces (factual) - due to temperature differences they stay in the air, and such traces may be revealed using a thermal imaging camera. Memory traces - remain in human memory, and are disclosed during interrogations (Kozdrowski, 2012).

Traces distinction may also occur according to the size of a trace- macro and micro traces - 'poorly visible or invisible to the naked eye particles of matter or features of physical activity, related to the event', and macro traces - include easily seen objects, or prints e.g. footprints (Bąkiewicz, 1996). T. Hanausek divided traces according to the name of the laboratory where traces are tested: dactyloscopic traces - inter alia fingerprints, mechanoscopic traces - inter alia traces of tools, traces of use of firearms - among others cartridge shells, missiles, trace evidence - inter alia footprints, traces of vehicles, chemical traces-inter alia stains, marks on documents and equipment designed to create them - inter alia typewriters, copiers, computers, thermal traces - temperature changes, phonoscopic traces - sound traces, osmological traces - odour traces, micro trace - traces that may be disclosed only and exclusively using appropriate methods employed by forensic laboratories, inter alia DNA, hair, biological traces - inter alia blood traces, secretions and excreta. Gradually, some areas have begun to penetrate therefore the division was considered as incorrect (Kozdrowski, 2012).

Depending on the stage of a process, forensic traces may be used as evidence as well as a subject of interest in detection activities. Situations appear when a given function does not occur at a given stage of the process, then other function plays an important role in the process. According to H. Kołecki one may distinguish the following functions of forensic traces:

- identification function based on testing of forensic traces. The tests ultimately aim to determine the perpetrator of a crime, by establishing the person, animal, objects, from which the trace comes from (Kędzierska, 2011);

- evidential function a basic function in the evidence proceedings during a criminal case. A trace in the sense of evidence proves something, speaks for something, and indicates something, it also has an adequate justification. However, if a trace could go to the court as a factual evidence in the case, it must be reliable. In connection with the principle of free assessment of evidence, the court has the right to question the evidence and consider it unreliable. Therefore evidence should be adequately preserved in two aspects: procedural and forensic. As far as proceedings are concerned, the evidence should be included in the inspection protocol with attached file, made photograph, as well as forensic sketch with a place and its position on the scene of the incident. Whereas in forensic sense, the evidence should be secured in a physical way to avoid destruction, damage, deformation or theft (Kozdrowski, 2012);

- registration function refers to the Police database in terms of forensic evidence that after years still presents evidential value. The evidence located in forensic databases come from proceedings in which the perpetrator was not immediately detected, however, it is still possible. Commonly, a registration function is regarded as a thesis to save from oblivion (Kozdrowski, 2012);

- associating and reactivating function consists of the following elements: combining something into one whole and applying it to the resumption of the activity. From a practical point of view it is about the association of traces from crimes with the traces in the databases. Consequently, it is possible to reopen proceedings that have been cancelled some time ago;

- organisational function deals with the organisation of work on a trace. Along with the disclosure of the trace, the operation begins concerning the preparation and undertaking of activities both procedural and forensic e.g.: determination of forces and means needed to capture a person, hearing witnesses and blocking the area;

- reconstructive function intends to reconstruct the course of events so that it would be the most compatible with the reality. It is worth remembering that the reconstruction should be only one, such as the material truth is only one. It may happen that certain data will be missing, which results in deficiencies in the reconstruction, often 
impossible to complete. During the reconstruction of the course of events one must take into account the place of the event, the type, time and the way in which the act was accomplished. In a nutshell, the reconstruction phase refers to the recovery of the events based on forensic evidence disclosed in a given place;

- designating function is supposed to select the perpetrator of the crime based on a trace by specifying e.g.: gender, age, personality, action motive, force, as well as the background of the perpetrator;

- version function refers to the manner in which the case will be presented. A version may be detailed or general, an event or personal. The version function is partially connected with the reconstructive version, because from several versions, only one may be true, being at the same time a reconstruction of a given event. Versions include time before the incident, during preparation and at the time of the offence. However, traces are the most important, without them it would not be possible to create various versions of events;

- verification version is designed to check and confirm the authenticity of the event. According to the type of a trace available to the Police, verification version is supposed to control the fact if information obtained is reliable and may be taken into account in a case. The function is directly connected with the designating, version and reconstructive function (Kędzierska, 2011);

- informational function relates to skilful reading of coded information. It is mainly employed at the place of the event and it refers to actions of the person examining the traces at the crime scene, one's ability to observe and think as well as one's professional experience (Kozdrowski, 2012);

- preventive function is of preventive and precautionary importance. The task of forensic prevention is to make it difficult to commit a crime, using physical protection. While the task of preventive forensics is to make it impossible to commit the intended crime. The difference between the terms of preventive and precautionary actions is minute, and in practice, it is hard to define whether a given action is prophylaxis or prevention. Both of these phenomena complement and permeate each other. (Kędzierska, 2011).

\section{IV.TRASEOLOGY}

Traces of shod, attire or bare feet are the most typical traces of all forensic examinations of criminal activity of a perpetrator inspection. Traces of footwear should be located in every place of inspection, which results from logical thinking: the perpetrator must get to the place of his action, stay in it and evacuate from it. Every perpetrator leaves traces of movement and action. The most important thing is to consistently look for and secure traces, engaging in the activities the advances of technology and intuition (Rodowicz, 2000). As a result of the impact of both the human and the object on the substrate, the tracings of a given object appear on the substrate. If the substrate is hard, it may happen that there will be marks on the object indicating contact with the specific substrate (Widła, 2016).

"Traseology - a field of forensic technique, dealing with the study of traces arising as a result of the movement of people, animals or means of transport intended for the movement of people, animals or things" (Lachacz, 2001). In traseology one can distinguish three types of traces: traces of human feet, traces left by animals, traces of vehicles (Miś, 2007).

The durability of the trace may be primarily affected by the weather conditions, as well as the presence of unauthorized persons, animals and vehicles at the scene. These elements may affect the removal of traces left. However, it should be remembered that such removal of traces can be both accidental and intentional (Jagiełło, 2011). The oldest criminal trace is the footprint of the bare foot (Kasprzak, Młodziejowski and Kasprzak, 2015).

In traseological studies, the concept of individualization of features was introduced by L. Rodowicz. The concept distinguishes group features - for example, the shape and structure of the soles, pattern, size, etc., individualizing features incorporating performance parameters - rips in the sole location, grade and range, and production features - the material from which the sole was made, from which mould, finishing glued, honed, cut. The author also indicates individual characteristics in the form of classical functional features tears, scratches, cuts and non-classical features - additional elements in the substrate, e.g. small stones, tacks, repairs, sticky substances, as well as production features - pattern layout relative to the bottom edge cut from the artificial material used for producing soles, air bubbles.

T. Szynawa, a court expert in the field of traseology of the KWP Forensic Laboratory in Katowice, dealt with research on the production features of a sole of a shoe. He distinguished three types of features, i.e. group features - permanent defects of form, type of pattern, construction of form; individualizing features - defects: acquired form, dirtiness of the form, loss of smoothness and pitting of corrosive forms; individual features - released air bubbles, a system of non-released air bubbles, short-run castings, deadheads. Group traseological features, e.g. in the form of footwear soles, are created during the production process, while individualizing and individual features are acquired during the use. On this basis, it can be concluded that both individual and individualizing characteristics can be interpreted as the effect of destruction and imperfection of group features. Traseology in its research is based on individual identification features. A feature of individualization can be defined by any feature that, to some extent, relates individually to the source of the trace (Moszczyński, 2011).

The mechanism of footprints is based on contact between a bare foot, a shod one or attired one with soil, snow or other hard surface. In soft ground one can pay attention to traces recessed otherwise known as imprints, while on the hard substrate the so-called surface traces appeared otherwise known as prints. The division of surface marks is as follows: accumulatedpositive and delaminated - negative three-dimensional. On a substrate such as asphalt, parquet or floor, surface marks are created. These include the part directly in contact with the 
surface. The results of applying the substance to the substrate are layered prints, whereas the delaminated ones are created as a result of taking substances out of the substrate (Miś, 2007).

The author distinguishes barefoot elements in both prints and footprints. These are the toes, the front part, the bridge part, the heel, the inner edge and the outer edge. Taking into account the shod foot, one can pay attention to such elements as zip, heel, toe tip, back edge, inner and outer edge of sole, part of the bottom, front heel of the heel, inner edge and external edge of the heel (Kędzierski, 2011).

An important element in traseology, apart from traces, is also the gait path (gait image) of the so-called ichnogram - an area in which footprints were left with a set of characteristics for a given person. The elements of the ichnogram include walking lines, walking direction and foot angle, foot length, foot width, step angle, step length and step width (Miś, 2007). The traces left by animals include paws, hooves, cloven feet (Miś, 2007). These traces are secured very rarely and are not often used (Jagiełło, 2011).

During the inspection of the crime scene, one often encounters traces from various means of transport. These are mainly tire tread mappings, while tracks of the vehicles on tracks or runners are rare. Due to the construction of the vehicle, one can distinguish traces of two-wheeled vehicles, traces of four-wheeled vehicles, traces of three-track vehicles, tracks of four-track vehicles, horse-drawn vehicles, sleighs, skis, tracks. On the road and on the hard shoulder there are vehicle traces such as: skid marks, slip marks, wheel blocking traces, driving tracks, traces of parking, traces of swerving, traces of gouging, traces of stop, traces of dragging, traces of rims (Miś, 2007).

In most cases traseological traces are revealed by the optical method, however, there are situations in which the trace is poorly visible or invisible; in such cases devices using the electrostatic properties of MES are used (Miś, 2007). The initial stage of protecting traseological traces is photographing, which is the basic method of securing traces of shoes seen with the naked eye. The photograph is taken from a height directly above the track, so that the picture includes the entire track along with the angle scale. In the light falling diagonally, small details will be better visible. In the case of embedded marks, the best solution is to take several shots casting light from different perspectives (Moszczyński, 2011). In order to protect the embedded trace, a gypsum or silicone cast is made (Miś, 2007). The material most often used for this is a dental stone and casting mass - used on a daily basis in dentistry. We can also use wax, silicone mass or stearin in some cases. Before starting the process of casting, remove all traces of contamination such as: pebbles, lumps, leaves, etc. Then, if the trace is on a loose substrate such as sand, it should be sprayed with hairspray or acetylcellulose solution. On the snow a spray wax will be used as the equivalent of the varnish, and after a while the casting will form. Special care should be taken when making casts (Moszczyński, 2011). In the case of revealing surface marks deposited on the substrate, it is important to protect the trace along with the ground, e.g. the shoe imprinted on a piece of paper (Miś, 2007). At that time, no other forms of securing are undertaken (Moszczyński, 2011).
In the case of a trace found on the floor, it is protected with gelatine dactyloscopic film (Miś, 2007). However, on nonabsorbent substrates, as in the case of fingerprints, traces are revealed using fingerprint powders. Then such a trace is transferred to the previously mentioned dactyloscopic film, adapted in size to the protected trace.

There are also traces of dust, which can also be transferred to the film. In the case of invisible dust traces, electrostatic film is used, which allows revealing traces among others on concrete substrates and carpets. This method is based on the arrangement of a vinyl film on the substrate on which the aluminium foil is spread - which serves as an electrode loaded with the use of a special device. Electrostatic field created thanks to this method electrifies and attracts shoe pollen to the film (Moszczyński, 2011). Each time photos of traces are taken along with the scale, in addition, each trace should be accurately described in the inspection report (type of trace, track number, location, dimensions, pattern of the sole and method of revealing and protecting the trace), and the protected trace should be provided with a certificate (Miś, 2007).

Via traseological traces left by different types of tires, one can determine exactly what kind of tire it is, what is the tread pattern and what is the degree of wear of the tire, which company produced the tire and what type of car they are used for. Tire marks occur mainly in cases of visual inspection of the place of a traffic accident and are most often the signs of braking, blocking, skidding, swerving, rim (if the tire is cracked) - all these features allow to determine the direction of travel and the speed at which the car was travelling at, as well as what manoeuvres were made while driving or whether the braking system had some drawbacks. Thanks to this information, it is possible to perform a reconstruction of a road accident. Traces of tires are secured in the same way as footwear traces, while traces of animals are extremely rarely secured (Moszczyński, 2011).

Traseological expertise is an expertise that requires a lot of work, where subjectivity and the expert's intuition play an important part (Wójcikiewicz, 2009). High level of subjectivism is associated with the evolution of individualizing features and changes in detailed characteristics when the time between securing the evidence trace and comparative footwear is too long (Moszczyński, 2011). In this case, however, it would be possible to consider the psychological opinion with the help of another expert, which would aim at eliminating subjectivism, possibly through meta-opinion. Analysis of the value of traseological research turns out to be quite high after all (Wójcikiewicz, 2009).

\section{V.SELECTED CASUISTIC CASES}

In the $1990 \mathrm{~s}$, a hand-made tracing base was created in the Forensic Technique Complex of the Municipal Police Headquarters in Bielsko-Biała. It consisted in drawing up forensic sketches by technicians, depicting patterns of shoe protectors that had previously been secured at the scene. The sketches were stored in binders, which the policemen used to 
compare footwear traces at other occurrences. It made it possible to single out in what crimes the perpetrator, whose shoe served as an example probably took part.

In the first decade of the 21 st century, however, another traseological base was created. This time, its function consisted of photographic documentation by a forensic technician serving the crime scene of the incident. It contained a photo of a trace left by the sole of the footwear and the appropriate case number for which it was secured. Other crimes attributed to the perpetrator after his detention were also typed on the basis of such data. Negative photography, produced on the spot, in the Municipal Police Headquarters in Bielsko-Biała, was used to take photographs of this type of traces. The photographs were collected so that they could be used for comparative analysis.

The breakthrough, however, turned out to be the introduction of digital cameras for technicians serving event venues. They were used to take photos of the pattern of the sole of the footwear, secured on the forensic film. Then they were located in a special folder that contained a collection of traseological traces. It allowed to create a base that enabled grouping and typing events, and comparing photos over the years. This made it possible to name the perpetrator whose pattern of the sole of the footwear was already in the base. It was a huge step forward for the Forensic Technique Team, because on its basis a lot of positive results were obtained, among others due to photos of footwear soles of detainees.

This method found practical application in tipping the mugger, among others at the hairdresser's, banks and many commercial establishments. One of the most interesting cases was the detection of the perpetrator of many burglaries that took place in 2002-2005 in the area subordinate to the Police Headquarters in Bielsko-Biała. The incidents occurred on average at intervals of two days, sometimes from day to day. The perpetrator burgled into the flats, using his method of burglarizing, forcing the balcony doors or windows. The perpetrator tried to work in gloves, however, during one of such events, fingerprints were secured, which were identified by the fingerprint expertise. In addition, on the burglary site, three traces were secured, which served as a comparative material. Thanks to this, the Police selected an accused who later admitted to the alleged deed. The collected evidence was also compared with the old, unresolved burglary cases. After inspection of the files and traces, traces coincident with the pattern chosen as a comparative material were found (about 180 of them were selected). An expert in the field of traseology was appointed to examine these matters. Having investigated each trace, he determined that the evidence footwear tracks and comparative evidence that was secured were deposited with the same footwear. He showed individual characteristics and on this basis the detainee was accused of committing about 160 burglaries and was sentenced to multiple prison sentences.

Another issue worth mentioning is the detection of a criminal group operating in Bielsko county. As in the case of the previously described story, it concerns burglaries. This time, however, they were made in detached houses. The group's members operated in various configurations, often checking beforehand the operation of services in the area. It consisted in breaking in the chosen district and observing when the reaction would take place. It helped them to prepare for further burglaries in this area. The perpetrators used various shoes, which meant that the traces of the different bottoms of the footwear were secured on the crime scene. Each of them went to the Municipal Traseological Registers, in which about 200 burglaries into detached houses were selected. The perpetrators admitted to committing these crimes and were convicted.

The described cases are only a small percentage of positively solved events based on a traseological database. Every time when working on this type of crimes, an expert in the field of traseology is appointed, who gives an opinion on traces, evidence and comparative material. An important element that has an impact on the detection process is therefore the collection of traces of the soles of footwear secured at the crime scene in the Municipal, County and Provincial Traseological Registers. The use of traseological databases to compare the protected traces and then the typing of footwear patterns will significantly contribute to the detection of the perpetrators of crimes. At the current stage traseological databases are not frequently used, which translates into the number of preparatory proceedings detected on the basis of traseological traces. Analysis of the secured evidence in the proceedings will help in identifying the offenders and perpetrators. The creation of a centralized traseological database should be considered here, which will certainly increase the detection.

\section{VI.CONCLUSIONS}

The proper use of the collected forensic evidence improves the security in an area. This is related not only to the increasing effectiveness of the identification of traseological traces, which affects the effective detection of 'perpetrators', as well as the social awareness itself. The perpetrators are guided by the fear of inevitable identification of traces and linking them to the crime scene. The enlarged database of traseological traces used in the Voivodeship Trace Evidence Register and then in the Municipal and County Registers of Traseology will also have a significant impact.

Every technological change will be connected with a growing number of databases of traces, and most importantly with the speed of their processing, which is important in detecting the perpetrator of the crime. It is worth adding that throughout the history research on traces has been and is an indispensable field in revealing and identifying perpetrators. Tracing research will play a significant role in improving the safety of residents. Correct identification of the perpetrator of the crime on the basis of traseological traces in the area subordinated to the Municipal Police Headquarters in BielskoBiała contributes significantly to identification and then convicting perpetrators of crimes. A high rate of categorical opinions indicates that the appointment of an expert in the field of traseology brings unquestionable benefits in detecting offenders, which also affects the conviction of judges about the guilt of the suspect. 


\section{REFERENCES}

Bąkiewicz, J. (1996). Pojęcie, rodzaje i znaczenie śladów kryminalistycznych (materiały pomocnicze). Słupsk, p.8.

Hanausek, T. (1975). Kryminalistyka jako naukowa podstawa działalności organów Milicji Obywatelskiej i Służby Bezpieczeństwa. Prace Prawnicze UJ, $71, \mathrm{p} .82$.

Hanausek, T. (1994). Zarys taktyki kryminalistycznej. Warszawa, p.117.

Hołyst, B. (2010). Kryminalistyka. Warszawa, pp.477-478.

Jagiełło, D. (2011). Kryminalistyka. Przegląd podstawowych zagadnień taktyki, techniki i profilaktyki kryminalistycznej, Skierniewice, p.82.

Kasprzak, J., Młodziejowski, B. and Kasprzak, W. (2015). Kryminalistyka Zarys systemu. Warszawa, p.135.

Kędzierska, G. (2007). Identyfikacja kryminalistyczna. Technika kryminalistyczna, 1(1), p.52.

Kędzierska, G. (2011). Charakterystyka śladów kryminalistycznych. In: G. Kędzierska and W. Kędzierski, ed., Kryminalistyka wybrane zagadnienia techniki. Szczytno, pp.28-37.

Kędzierski, W. (2011). Ślady traseologiczne. In: G. Kędzierska and W. Kędzierski, ed., Kryminalistyka. Wybrane zagadnienia techniki. Szczytno, p.26.

Kozdrowski, S. (2012). Kryminalistyka. Białystok: Niepaństwowa Wyższa Szkoła Pedagogiczna, pp.75-78, 94.

Kulicki, M. (1994). Kryminalistyka wybrane zagadnienia teorii i praktyki śledczo-sądowej. Toruń, p.18.

Kulicki, M., Stępka, L. and Kwiatkowska-Wójcikiewicz, V. (2009). Kryminalistyka. Toruń: Wydawnictwo Naukowe Uniwersytetu Mikołaja Kopernika, p.17.

Łachacz, M. (2001). Traseologia. In: W. Pływaczewski and G. Kędzierska, ed. Leksykon policyjny. Szczytno, p.345.

Miś, W. (2007). Ślady kryminalistyczne. Piła, pp.26-29.

Moszczyński, J. (2011). Subiektywizm w badaniach kryminalistycznych. Przyczyny i zakres stosowania subiektywnych ocen $w$ wybranych metodach identyfikacji człowieka,. Olsztyn, pp.186-188, 197, 491-494.

Moszczyński, J. (2011). Subiektywizm w badaniach kryminalistycznych. Przyczyny i zakres stosowania subiektywnych ocen $w$ wybranych metodach identyfikacji człowieka,. Olsztyn.

Moszczyński, J. (2016). Dylematy identyfikacji indywidualnej i grupowej. In: M. Goc, T. Tomaszewski and R. Lewandowski, ed., Kryminalistyka - jedność nauki i praktyki przegląd zagadnień z zakresu zwalczania przestępczości, Warszawa, pp.179-180.Kędzierska, G. (2007). Identyfikacja kryminalistyczna In: W. Kędzierski, ed., Technika kryminalistyczna Vol. 1. Szczytno, pp.50-58.

Rodowicz, J. (2000). Kryminalistyczne badanie śladów spodu obuwia. Warszawa, p.7.

Widacki, J. (1984). Kryminalistyka Part 1. Katowice, p.157.

Widła, T. (2016). Identyfikacja narzędzi, śladów obuwia i śladów pojazdów. In: J. Widacki, ed., Kryminalistyka. p.357.

Wójcikiewicz, J. (2009). Temida nad mikroskopem. Toruń, p.102. 